Journal of Maternal and Child Health (2016), 1(4): 250-256

https://doi.org/10.26911/thejmch.2016.01.04.06

\title{
Effectiveness of the Expanded Maternal and Neonatal Survival Program in the Reduction of Maternal Mortality in Tegal, Central Java
}

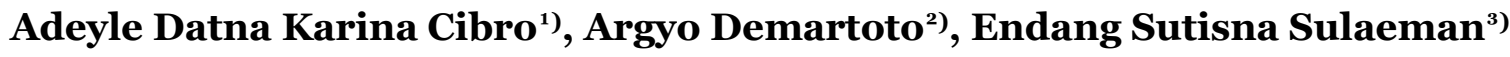 \\ ${ }^{1)}$ Masters Program in Public Health, Universitas Sebelas Maret \\ 2)Faculty of Social and Political Sciences, Universitas Sebelas Maret \\ 3)Faculty of Medicine, Universitas Sebelas Maret
}

\begin{abstract}
Background: Maternal mortality rate is one of the sensitive indicators of population health in a country. Various measures have been implemented to reduce maternal mortality rate, including the Expanding Maternal And Neonatal Survival (EMAS) program. This study aimed to evaluate the effectiveness of the Expanded Maternal and Neonatal Survival program in the reduction of maternal mortality in Tegal, Central Java.

Subjects and Method: This was a qualitative evaluative study using context, input, process, product (CIPP) framework. This study was conducted in Tegal, Central Java. The data were collected by in-depth interview, observation, and document review. The primary key informants of this study consisted of 10 subjects, including EMAS team, Head of the District Health Office Tegal, Head of Pagerbarang Health Center, Head of Dukuhwaru Health Center, their coordinating midwife, and community as the program beneficiary.

Results: EMAS program was implemented in Tegal because of high maternal mortality rate and lack of community awareness on the importance of visiting health care facility. During the program implementation the district government synergized various stakeholders to realize good governance. Stakeholders work together according to each other task and function. EMAS program has resulted in improved skill of the doctors, midwives, and nurses in tackling emergency cases, so that the emergency cases can be tackled faster, and community awareness use health facilities. The barrier factor was the insufficient number of mentoring health personel.

Conclusion: The EMAS program in Tegal district, which aims to reduce maternal mortality rate has been implemented effectively. The emergency referral system is well implemented. Working groups had performed tasks and functions well with adequate responsibility.
\end{abstract}

Keywords: evaluation, EMAS program, maternal mortality rate

Correspondence :

Adeyle Datna Karina Cibro. Masters Program in Public Health, Sebelas Maret University, Surakarta. Mobile: 085642596407.

\section{DISCUSSION}

Efforts to improve maternal, newborns and children health have become the government's top priorities. This is in line with the objectives of the Sustainable Development Goals (SDGs) where one of the objectives is to improve maternal health through a reduction of Maternal Mortality Rate (MMR) by assisting labors with trained health workers (SDGs, 2015)
Maternal Mortality Rate (MMR) is one of the main indicators of health status of a country. MMR also indicates the ability and quality of health services, health service capacity, quality of education, knowledge of the community, quality of environmental health, socio-cultural, as well as barriers in obtaining access to health services. The mortality and morbidity of pregnant women during labor and puerperium is a major problem in developing 
countries. MMR is the death of women during pregnancy or death within 42 days after the end of pregnancy without considering the age and type of pregnancy. Complications of labor or puerperium are related or aggravated by pregnancy and management of pregnancy, but not by accident (WHO, 2012)

According to the study of Haver et al., (2015), the implementation of a health program is planned to reduce maternal and infant mortality by the existence of an institution that facilitates the health community. Whereas according to Shimoda's study (2015), medical interventions were adjusted to the case characteristics and manpower. It starts with the initial meeting, monitoring, implementation. So, midwives can recognize dangerous signs on patients so they can identify problems and deal with them well. A study conducted in Tanzania found that one of the things that was done in reducing MMR was by evaluating the health system as well as the existence of policies and consideration of changes seen in terms of economics and education.

In Indonesia, the quality of the health of pregnant women and mothers giving birth is still not good with the MMR and IMR indicators are still high. The causes of maternal mortality in Indonesia are very complex, both direct and indirect or basic causes. There were $42 \%$ bleeding, $13 \%$ eclampsia, $11 \%$ abortion complications, $10 \%$ infection, and $9 \%$ long labor cases. While the causes of infant mortality are neonatal problems, such as aphyxia, low birth weight babies (LBW), and neonatal infections. Another problem that can cause maternal and infant mortality is the problem of malnutrition and under nutrition. The high mortality rate is a reflection of the quality of maternal and child health services that still need to be improved.
The number of MMR in Tegal in 2015 was 33 cases. This has decreased compared to 2013 with 51 cases and 2014 with 47 cases. However, Tegal is still ranked as the fifth highest in the MMR compared to other regencies or cities in the province of Central Java. The causes of MMR were anemia as many as 2 people, eclampsia 3 people, bleeding 8 people, chronic energy shortages 1 person and other causes 19 people. Because of the high MMR, a system is needed to accelerate the decline in MMR.

Efforts to accelerate the reduction of MMR have been carried out through increasing accessibility and quality of services carried out by health services closer to the community through the placement of midwives and Integrated Services Post in various remote villages and doctors in remote or very remote areas. While from the aspect of service quality, efforts were made are to improve the competence of health workers, basic health facilities, and referrals (BEmONC/ CEmONC), as well as other intervention programs.

The program implemented for MMR acceleration is The Expanding Maternal and Neonatal Survival Program (EMAS). EMAS program is collaboration between the Ministry of Health of the Republic of Indonesia (Indonesian Ministry of Health) and United States Agency Development (USAID) to assist Indonesia in reducing MMR. The program is implemented in 30 districts from 6 provinces in Indonesia which have the highest MMR, namely West Java, Central Java, East Java, Banten, North Sumatra and South Sulawesi. Through this EMAS program, it is expected that MMR can be reduced by as much as $25 \%$ through improved management of obstetric emergency cases. The aim of the EMAS program is to improve the quality of emergency services in hospitals and health 
centers and also to strengthen the referral system between community health center and hospitals to be more efficient and effective. Efforts that will be carried out are improving the quality of obstetric and neonatal emergency services by ensuring priority medical interventions that have a major impact on the decline and clinical governance carried out in hospitals and health centers. Another effort of EMAS program is to strengthen efficient and effective referral systems in basic health care facilities in health centers to referral hospitals at the District / City.

Besides that, the participation of the community is expected to reduce MMR because with the high participation of the community, the community will be able to help themselves in recognizing and solving problems and fullfiling the needs of the community. One of which is to bring pregnant women to have a pregnancy visits and delivery at a health facility. To improve maternal health, collaboration among the government, health services and the community is expected.

The existence of community participation is linked to the Health Belief Model (HBM) theory where this theory is based on the understanding that someone will take actions that will be related to health. The health belief model is a model that explains the existence of one's knowledge of health threats and an understanding of behaviors that are suggested to prevent or overcome health problems based on feasibility and profit assessment compared to costs. The factors that affect health in individuals include background, perceptions and actions. While one of the goals of this HBM is that individuals are ready to change behavior (Kevin, 2005).

With EMAS program, it is expected that all pregnant women have the awareness to check their health to the health facilities. The program also developed a feedback mechanism from the public to the Regional Government using information technology such as social media and SMS gateways, and strengthened community forums to demand more effective and efficient services through service charter.

This study aims to analyze the effectiveness of EMAS program on maternal health services to reduce maternal mortality in Tegal.

\section{SUBJECTS AND METHOD}

This study was qualitative study using an evaluation method with the Context, Input, Process, Product (CIPP) approach and carried out in Tegal. Data collection was done by conducting in-depth interviews, observation and document review. The main informants in this study were EMAS team, the Head of the District Health Office Tegal, the Head of Pagerbarang Health Center and the coordinating midwife, the Head of the Dukuhwaru Health Center and the coordinating midwife, and the service recipient community.

\begin{tabular}{l}
\hline RESULT \\
The background of the implementation of \\
EMAS Program in Tegal was because the \\
number maternal mortality in Tegal was \\
quite high. This could be seen from the \\
results of the Maternal and Neonatal Audit \\
in Tegal which stated that the skills of \\
health workers were not yet competent, \\
especially in dealing with emergency cases. \\
Public awareness of health were still \\
lacking. With this EMAS program there \\
would be an increase of skills of health \\
workers through various trainings and also \\
Community participation in this case was \\
the role of community leaders. \\
The implementation of EMAS \\
program in Tegal had been carried out in
\end{tabular}


accordance with established procedures both from the health care system and referral system. This also could be seen from the work of all working groups related to their respective duties and responsibilities.

Supporters of EMAS Program in Tegal were all working groups that had been determined since the beginning of EMAS Program in Tegal, as well as sufficient human resources. Whereas, the obstacles from the EMAS Program in Tegal were not all community health centers in Tegal were able to conduct BEmONC and human resources that become mentors have not fulfilled yet.

The results that had been achieved from EMAS in Tegal program were the number of emergency cases was decreasing because it was quickly and precisely handled and the referral system was getting better. In addition, public awareness of health, especially for pregnant women, maternity and childbirth, was increasing with the increasing number of pregnant women were being seen to have their health checked at the integrated services post or community health center, also the awareness of taking pregnancy classes.

Context Tegal Regency is ranked in the top 5 in the high MMR as many as 33 cases in 2015 .

Competent personnel are needed to improve health services, especially midwifery, in handling emergency cases so that they can provide first aid before making referrals.

Build effective networks to strengthen the referral system to accelerate efforts to reduce the MMR by collaborating between facilities in Tegal Regency. This refers to the Regulation of the Minister of Health of the Republic of Indonesia Number 1 of 2012 concerning the Referral System

It takes citizen participation to voice the interests of the community, demand their right to get better service and convey their views to service providers and the government in a responsible and quality manner

Input During the EMAS Program in Tegal, the personnel were consisted of EMAS team, Tegal District Health Office, health service providers or doctors, and midwives and nurses who had worked well.

SOP was made in written form and contain work procedures (process flow) in detail and systematically. In the implementation of the EMAS Program, each working group had its own SOP.

In this EMAS program, all budgets were disbursed according to initial budget planning. Budget preparation was done carefully.

In the EMAS program, the facilities and infrastructure in the information system were quite good. The existence of SMS gateways could overcome maternal and child emergencies and improve health workers' abilities to apply the system.

Process After the socialization of EMAS program was held to all relevant stakeholders, policy formulation was carried out based on the orientation of the decreased number of maternal mortality rates, determining the program of activities that must be synergized with the data.

In implementing EMAS program, each community health center had contributed by picking up the participants if there were people who did not want to follow, for example the pregnancy class. This will be discussed when there was a 
meeting with the EMAS team.

The management and resources implemented in the EMAS program were managed by all relevant stakeholders, in this case the main managers were the EMAS team in Tegal. The aim was to overcome the high maternal mortality rate in Tegal Regency, with coordination, consistency and priority setting.

The obstacle of the EMAS Program in Tegal was that not all community health center in Tegal had been able to implement BEmONC. In addition, personnel who became mentor must be well equipped.

The EMAS program in Tegal lasted for 2 years. However, the program's activities continue because it hasd the effect of decreasing MMR and IMR.

Output The increased awareness of pregnant women following the activities in the pregnancy class, integrated services post and Village Health Polyclinic (PKD) held by midwivesof Pagerbarang Health Center and Dukuhwaru Health Center in Tegal.

The long-term impact that can be generated from this activity is the community can be aware of the importance of checking and giving birth in health facilities that have been provided. The expected follow-up is that the community continues to seek treatment at health care facilities.

Activities that have been running are expected to be sustainable and can provide great impact and benefits for the community in particular and also enthusiasm in maintaining their health during pregnancy, childbirth and puerperium.

The involvement of various stakeholders and the commitment to continue to support the implementation of this program is important because many cases of maternal mortality are not only the government's responsibility. Synergistic relations between society, government and health services are important in realizing good governance.

The communication that is established among program implementers was quite good. The communication with the target community of the EMAS program had also been carried out quite well through socialization.

Program implementers had a high commitment to the implementation of the EMAS program. A high level of commitment appears in both community health centers.

\begin{tabular}{l}
\hline DISCUSSION \\
\hline The high maternal and infant mortality \\
rates are still the main focus in a country. \\
For this reason, the EMAS program was \\
implemented in Tegal. The program was \\
socialized and at the same time a working \\
group was formed consisting of various \\
elements of health both directly involved in \\
handling mothers and babies such as \\
doctors, midwives and nurses or other \\
supporting elements such as community
\end{tabular}

organizations, which would support the EMAS program.

The results of the study on the high MMR stated that many efforts to improve maternal health were prioritized on expanding quality health services, comprehensive obstetric services, improving family planning services, and disseminating information and education to the community. The results of this study were reinforced by the theory which says that one of the achievement targets in the 
program of reducing MMR and IMR is by strengthening the community so that the objectives of a program can be achieved.

In achieving the objectives of EMAS program, a Vanguard (frontline) approach was adopted where the EMAS program had a target of reducing MMR by $25 \%$. After the EMAS program was held, the number of emergency cases such as preeclampsia was reduced due to immediate follow up. Each community health center was required to make reports relating to the EMAS program and the EMAS team will receive a report from the Tegal Health Office. The purpose of this report was to review cases that occur continuously so that it was expected that if there was a similar case it could be handled properly. This shows that the community health center has carried out a referral system well, namely vertically with the transfer of patient. Reducing MMR is not an easy case. Development of appropriate program strategies and policies is needed and right on target. The government is unable to cope with the high maternal and infant mortality itself without the support and participation of the community, health workers, and community leaders. Public awareness is needed to carry out regular pregnancy checks and deliveries at health workers. So that it is expected that through this EMAS program, the number of maternal deaths can be reduced in such a way.

This study concluded that the implementation of the EMAS program in Tegal to reduce MMR was effective because the functioning of the emergency referral system for mothers and infants was effective, efficient and fair. Working groups have different tasks and responsibilities.

Stakeholders participating in the EMAS program worked according to their respective duties so that there were no significant difficulties in implementing this program. Existing constraints could be overcome properly.

\begin{tabular}{l}
\hline REFERENCE \\
\hline Aoshima K (2011). Neonatal Mortality Rate \\
Reduction by Improving Geographic \\
Perinatal Care Center in Japan. Japan \\
Azwar A (1996). Pengantar Administrasi \\
Kesehatan. Jakarta: Bina Putra. \\
Aeni N (2013). Faktor Risiko Kematian Ibu. \\
Jurnal Kesehatan Masyarakat Nasio- \\
nal Universitas Indonesia 7(10): 453- \\
459.
\end{tabular}

Agarwal K, Caiola N, Gibson A (2015). Best practices for a successful MNCH partnership that an external evaluation could never find: Experiences from the Maternal and Child Health Integrated Program. International Journal of Gynecology and Obstetrics 130: S11-S16.

Bhandari (2012). Effect of implementation of Integrated Management of Neonatal and Childhood Illness (IMNCI) programme on neonatal and infant mortality BMJ: 344 .

Departemen Kesehatan RI (2005). Pelayanan Obstetri Neonatal Esensial Dasar. (2007). Riset Kesehatan Dasar.

Dinas Kesehatan Jawa Tengah. (2012). Profil Kesehatan Jawa Tengah.

Haveret (2015). Experiences engaging community health workers to provide maternal and newborn health services.

John Hopkins University News (2012). Leads New Program in Indonesia to Reduce. Maternal Deaths by 25 percent. JHPIEGO.

Kemenkes RI (2012). Situasi Kesehatan Ibu. www.depkes.go.id.

Kemenkes RI (2013). Rencana Aksi Percepatan Penurunan Angka Kematian Ibu di Indonesia. http://www.gizikia.depkes.go.id. Diakses 26 November 2015 . 
Kemenkes RI (2014). Bidan berperan penting turunkan AKI dan AKB. Artikel Kesehatan. http://buk.depkes.go.id.

Mantra IB (1997). Monitoring dan Evaluasi, Penyuluhan Kesehatan Masyarakat. Jakarta.

Moleong L (2005). Metode Penelitian Kualitatif. Bandung: PT. Remaja Rosdakarya

The University of Melbourne (2011). Reducing Maternal, Newborn and Children Deaths in the Asia Pasifik. Melbourne University Press

United Nations Statistical Commision (2015). Technical report by the Bureau on the process of the development of a indicator framework for the goals and targets of the post 2015 development agenda-working draft.

Sanusi R (2013). Meningkatkan Program EMAS.https://rossisanusi.Wordpress. com. diakses tanggal 17 Oktober 2015

Shimoda (2015). Midwifes intrapartum monitoring process and management resulting in emergency referals in Tanzania.

Sulaeman ES (2013). Manajemen Puskes mas. UNS Press.

Sulaeman ES (2012). Manajemen Masalah Kesehatan. UNS Press.

Sulaeman ES (2013). Promosi Kesehatan. UNS Press

Syafrudin (2009). Kebidanan Komunitas. Jakarta: buku kedokteran

USAID (2015). Two Decades of Progress: Usaid's Child Survival and Maternal Health Program. http:/pdf.usaid.gov/pdf_docs/pdacno44.pdf.

USAID (2012). Buku EMAS Panduan Teknis Masyarakat Forum Madani.

Yahraninda C (2015). Implementasi Program EMAS untuk mengurangi Angka Kematian Ibu dan Angka Kematian Bayi (Studi pada Dinas Kesehatan Kabupaten Malang). Jurnal Universitas Brawijaya. 